\title{
JUURNAL.RU
}

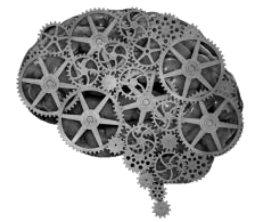

COMPANY GROUP "INTELLEKT"

Волшаник М.В. ФГБОУ ВПО «Саратовская государственная юридическая академия» Саратов, Россия

doi: 10.18411//j2016-9-3-03

idsp 000001: lj2016-18-3-03

\section{Национальная платежная система России и иные платежные системы как основа многосторонних расчетов в ЕАЭС}

\section{Аннотация}

В статье анализируютсяпричины создания национальной платежной системы Российской Федерации, а также целесообразностьобразованиясистемы многосторонних расчетов для Евразийского экономического союза.Целью анализа служит рассмотрениеособенностей национальной платежной системы Российской Федерациии выявление приоритетов аналогичных платежных систем для Евразийского экономического союза.

Ключевые слова: национальная платежная система, Евразийский экономический союз, платежная система, валюта, клиринг.

В начале 2015 года в силу вступил Договор о Евразийском экономическом союзе (далее - ЕАЭС), что стало предпосылкой начала экономической интеграции евразийских стран на новом этапе. Интеграция объединенных стран,основой которой является отсутствие препятствий для перемещения товаров, капиталов, рабочей силы, а также для валютно-финансовых операций между резидентами стран группировки, может превратиться в перспективе в остров валютной стабильности в окружении мирового валютного непорядка.

О том, что в мировой экономике уже многие годы отсутствует должный валютный порядок,констатировал еще в 2011 г. президент Франции Н.Саркози, выступая с докладом перед членами правительства. Он утверждал, что много лет 
мировая экономика существует в условиях бессистемности, а мировая система валюты была готова рухнуть вначале 70-х годов прошлого века.

Возникновение ЕАЭС ставит на повестку дня основной вопрос формирования платежной системы для осуществления стабильной структуры евразийских финансовых отношений. На данный момент в регионе расчетные отношения носят двусторонний характер, но для того, чтобы данные отношения между резидентами стран ЕАЭС благоприятствовали развитию финансовых отношений, необходимо создание эффективной платежной системы, которая могла бы предусматривать всеобъемлющее использование национальных валют и экономию издержек по расчетам. С данной целью можно присмотреться к опыту некоторых региональных союзов и платежных систем.

С момента включения Федерального закона №161-Ф3 от 27 июня 2011 г. «О национальной платежной системе» в список федерального законодательства все процедуры по налаживанию функционирования единой платежной системы в России стали законными. Под понятием национальной платежной системы (далее - НПС) следует понимать функционирующую на территории Российской Федерации целостную систему безналичных платежей за товары или услуги различных государственных или коммерческих организаций. Данный закон производит контроль таких аспектов функционирования НПС, как: поддержание частной деятельности заинтересованных субъектов НПС по последующему развитию инициативы в виде проектов в соответствии с государственной политикой в этой области; гарантия прозрачности расчетов и движения денежных средств, отводимых государством, на обеспечение деятельности НПС; наличие у потребителей услуг НПС защиты их прав и свободы действия в рамках законодательства; обеспечение безопасности всех участников системы и системы в целом. В другие области развития и функционирования системы государство не осуществляет вмешательство, т. к. создание НПС - это, прежде всего, бизнес, правда, на государственном уровне.

Основой НПС являетсясоблюдение принципов и требований участниками платежей при установлении участника операции и исполнение самого платежа. Но этого недостаточно; для большего функционирования НПС нужно законодательное регулирование государством деятельности субъектов экономических отношений в части усовершенствования банковских 
инновационных технологий использования платежных карт и расчетов с их использованием. Целями создания НПС для Правительства РФ служат: упрочнение национального финансового рынка; укрепление государственного финансового сектора посредством поддержки российской валюты и всей финансовой системы России в целом; слияние разобщенных финансовоэкономических субъектов в единое целое. Данные процедурыпоспособствуют повышению авторитета российского банковского сектора на международной арене. Такого рода система станет основой для государственного распределения финансовых источников на внутреннем рынке страны.

НПС отличает от других систем ряд функций, которые законодательно не закреплены во многих платежных системах: основы функционирования специальных небанковских кредитных организаций; понятие электронных денег как формы расчетов (не обязательств); для идентифицированных пользователей - наборопераций, приближенный к системам интернет-банкинга; противодействие легализации (отмыванию) доходов, полученных преступным путем, и финансированию терроризма при расчетах с использованием электронных денег. Перечисленные функции показывают немалое количество перспектив и преимуществ перед другими платежными системами.

Опыт в сфере создания платежной системы для ЕАЭС можно позаимствовать в аналогичных многосторонних платежных системах: в одной из них участвуют десять южноамериканских стран, а также Мексика и Доминиканская республика. Срок данного соглашения не определен, и любая страна может выйти из данного договора. Основой системы являются соглашения о взаимных платежах и кредитах, заключаемые центральными банками данных стран на двухсторонней основе. Платежи и кредиты осуществляются в национальных валютах.

Сведения о платежах передаются центральным банком каждой страны в Центральный резервный банк Перу, далее он выполняет многосторонний зачет платежа в течение четырех месяцев и определяет итоговое сальдо центрального банка каждой страны по отношению ко всем центральным банкам, состоящим в системе. Если один из центральных банков стран-участниц в результате зачета оказался с отрицательным сальдо, то данный банк получает требование от агента о конверсии сальдо в валюту клиринга (доллар США) и о переводе этих 
сумм на счета центральных банков стран, оказавшихся итоговыми кредиторами. Для данного процесса каждый центральный банк имеет личный счет в Федеральном резервном банке Нью-Йорка. Преимуществом приведенной системы расчетов следует признать существенную экономию реальной валюты во взаимной торговле стран-участниц многостороннего клиринга.

К числу иных межгосударственных платежных систем относится и Азиатский клиринговый союз, в состав которого входят центральные банки таких девяти стран, как: Бангладеш, Индия, Ирани другие. Данный союз берет свое начало в 1974 году, его банком-агентом является Amu (Asianmonetaryunit), в его рамках действует азиатская валютная единица, счета которой функционируют в двух вариантах амю: «амю доллар» и «амю евро», они эквивалентны одному доллару и одному евро. Приоритетом данного союза является предоставление краткосрочных взаимных кредитов в размере 1/12 национального экспорта, а также получение кредита эквивалентного 1/24 импорта для покрытия остатка взаимных расчетов. Система такого типа помогает стабилизировать расчеты между государствами, тем самым минимизируя колебания в экономиках этих стран.

Большой опыт был накоплен и в рамках бывшего Совета экономической взаимопомощи, где многосторонний клиринг в переводных рублях предусматривал преимущественную форму расчетов - инкассо с немедленной оплатой, а экспортеры получали платежи в национальной валюте. Для снижения двусторонних расчетов в рамках СНГ в 1993 г. был создан Межгосударственный банк. Смыслом его создания служит поддержание экономической интеграции и совершенствование национальных экономик стран СНГ с помощью формирования механизма для проведения трансграничных платежей и кредитования внешнеторговых операций данных стран в национальных валютах, а также для участия в выполнении проектов, имеющих межгосударственное значение. Межгосударственный банк имеет прямой доступ к национальным платежным системам стран участников. Создание такой системы для ЕАЭС способствовало бы превращению системы в важный фактор поддержки взаимных финансовых отношений.

Таким образом, все вышеперечисленные платежные системы могут способствовать созданию многосторонней платежной системы для ЕАЭС, но по 
настоящему актуальной для интеграционного образования следует признать национальную платежную систему Российской Федерации. По сравнению с остальными данная система самая новая и создана для более современных условий.Проведя некоторые реформы иизменения, она послужит ЕАЭС в качестве многосторонней платежной системы, которая не будет зависеть от доллара или евро, а будет учитывать прямые интересы стран, входящих в ЕАЭС, положив конец царствованию доллара и евро.

\section{Литература:}

1. О Евразийском экономическом союзе: Договор от 29 мая 2014 г. (ред. от 10 октября 2014, с изм. от 08 мая 2015) // Официальный сайт Евразийской экономической комиссии http://www.eurasiancommission.org.

2. О национальной платежной системе: Федеральный закон от 27 июня 2011 N 161-Ф3 (ред. от 29 декабря 2014, с изм. от 01 марта 2015) СЗ РФ. 2011. N 27. ст. 3872.

3. Николаева Н.Ю. Национальная платежная система России и ее основной элемент - банковская карта // РИСК: Ресурсы, информация, снабжение, конкуренция. 2013. № 1. С. 266-269.

4. Кузнецов В.С. Валютный союз - будущее ЕАЭС // Вестник МГИМО Университета. 2015. № 2 (41). С. 250-258.

5. Межгосударственный банк. Общие сведения о банке // http://www.isbnk.org/ru/about.html (дата обращения: 16 сентября 2016). 